\title{
Problems of Teaching Phonological Awareness to learning disabilities students ${ }^{1}$
}

Problemas de la Enseñanza de la Conciencia Fonológica con Estudiantes con Dificultades de Aprendizaje

Mohamad Ahmad Saleem Khasawneh"

King Khalid University, Saudi Arabia

\footnotetext{
${ }^{1}$ Received. September 15th 2021/ Accepted: November 19th 2021

2 mkhasawneh@kku.edu.sa
} 


\section{Abstract}

This study seeks to identify problems related to teaching phonological awareness in English to students with learning disabilities from the point of view of their teachers in Irbid city. Jordan. The study also explored if gender and years of experience of the teacher affect their opinions toward the problems of teaching phonological awareness in English for students with learning disabilities. The study used online questionnaires to gather data from 140 teachers. The results showed that the problems of teaching phonological awareness in the English language for students with learning disabilities were of medium significance. As the problems related to the English language curriculum for students are very important. The problems related to the educational environment for students with learning disabilities were also of great importance. Finally, the problems related to the English language teacher in special education schools in Irbid city were of medium importance. The results also showed that there were no differences in the problems of teaching English for students with learning difficulties from the point of view of their teachers according to the variables of gender and years of experience.

Keywords Phonological awareness; problems of teaching learning disabilities; teaching English; teachers' attitudes.

\section{Resumen}

Este estudio busca identificar los problemas relacionados con la enseñanza de conciencia fonológica en inglés a estudiantes de con dificultades de aprendizaje desde el punto de vista de sus profesores en la ciudad de Irbid, Jordania. El estudio también exploró si el género y años de experiencia de los docentes afectan sus opiniones hacia los problemas de enseñar la conciencia fonológica en inglés para estudiantes con dificultades de aprendizaje. El estudio utilizó cuestionarios en línea para recopilar datos de 140 profesores. Los resultados mostraron que los problemas de la enseñanza de la conciencia fonológica en el idioma inglés para estudiantes con discapacidades de aprendizaje fueron de importancia media. Dado que los problemas relacionados con el plan de estudios del idioma inglés para los estudiantes son muy importantes. Los problemas relacionados con el ambiente educativo para los estudiantes con dificultades de aprendizaje también fueron de gran importancia. Por último, los problemas relacionados con el profesor de inglés en las escuelas de educación especial de la ciudad de Irbid fueron de mediana importancia. Los resultados también mostraron que no existían diferencias en los problemas de la enseñanza del inglés para estudiantes con dificultades de aprendizaje desde el punto de vista de sus profesores según las variables de género y años de experiencia.

Palabras clave: conciencia fonológica; dificultades de aprendizaje; enseñanza de inglés; estudiantes de colegio; problemas de la enseñanza de conciencia fonológica; experiencia de enseñanza 


\section{Resumo}

Este estudo busca identificar os problemas relacionados com o ensino de consciência fonológica em inglês a estudantes com dificuldades de aprendizado desde o ponto de vista de seus professores na cidade de Irbid, Jordânia. O estudo também explorou se o gênero e anos de experiência dos professores afetam suas opiniões aos problemas de ensinar a consciência fonológica em inglês para estudantes com dificuldades de aprendizado. O estudo utilizou questionários online para recopilar dados de 140 professores. Os resultados mostraram que os problemas do ensino da consciência fonológica no idioma inglês para estudantes com deficiências de aprendizado foram de importância média. Devido a que os problemas relacionados com o plano de estudos do idioma inglês para os estudantes são muito importantes. Os problemas relacionados com o ambiente educativo para os estudantes com dificuldades de aprendizado também foram de grande importância. Por último, os problemas relacionados com o professor de inglês nas escolas de educação especial da cidade de Irbid de importância média. Os resultados também mostraram que não existiam diferenças nos problemas de ensino do inglês para estudantes com dificuldades de aprendizado desde o ponto de vista de seus professores segundo as variáveis de gênero e anos de experiência.

Palavra chave: consciência fonológica; dificuldades de aprendizado; ensino de inglês; estudantes de colégio; problemas do ensino de consciência fonológica; experiência de ensino 


\section{Introduction}

The literature confirmed the existence of discriminatory problems between children with learning disabilities more than ordinary students. Some students with LDs may suffer from difficulties in visual discrimination, which includes difficulties in organizing and interpreting visual stimuli, and some of them suffer from difficulties in motor discrimination or general coordination and the synergy of body parts in particular. During movement and writing, some of them suffer from phonological awareness difficulties. The phonological difficulties have been theoretically linked to learning disabilities, as many researchers believe that the developmental deficiency of phonemic discrimination greatly affects the success of the reading process. The reading process entails the presence of analysis, sequencing, and remembering stimuli auditory. The more efficient the child is in analyzing words into single sounds, the better his reading level will be. Children with reading difficulties usually fail to distinguish the phonemic structure of the spoken language, whether at the word level or at the sentence level (Landerl et al., 2019).

Special programs for training in phonological awareness skills for students with LDs are of vital importance to face these challenges, as such category perceives things in a different way. Therefore, the existence of programs to develop phonological awareness skills for children with LDs has become an important element for developing their learning process. These programs call for the use of methods appropriate to the capabilities of the child, as the development of these abilities may positively affect the development of aspects of the personality, whether psychological or social, in addition to the fact that it is expected to raise their ability to academic achievement (Lederberg et al., 2019). This current study seeks to identify the problems of teaching phonological awareness in English to students with LDs from the point of view of their teachers.

\section{The problem of the study}

Several problems arise when teaching students with learning disabilities phonological awareness, which affect their performance negatively (Khasawneh \& Alkhawaldeh, 2020). Identifying those problems helps in the reduction of influences on the learning process of students with LDs. One of the main problems is the English language curriculums, which is a necessary element in the educational process. Students are supposed to understand the content of the curriculum by the help of teachers. However, some of these curricula lack relevance to the level of learning disabilities students. Sometimes students are not involved in the feedback on the content of these textbooks (Kwakkel et al., 2021). Some other problems are directly related to students with LDS. The level of disabilities among these students affect their levels of understanding and knowledge. The huge number of students in the classroom is also 
another major problem that hinder the progress in the educational process (Powell, \& Atkinson, 2021). The English language teacher is also a very important element in these problems. Many teachers lack the required training and they have large number of classes, which prevent them from self-development and progress (Zarić et al., 2021).

\section{Questions of the study}

1. What are the problems of teaching phonological awareness in English language to students with learning disabilities from the point of view of their teachers?

2. Are there any statistically significant differences about the problems of teaching phonological awareness in English language for students with LDs according to the variables of gender and years of experience from the point of view of teachers?

\section{Significance of the study}

It is hoped that the results of this study will benefit teachers of learning disabilities in English language by identifying the problems of teaching phonological awareness in English for students with learning disabilities. The results might also benefit parents of students by identifying the level of performance of teachers, as this is a major and important factor when sending their children to schools.

\section{Limitations of the study}

The current study included teachers of learning disabilities in English language in Irbid city only for the academic year 2019-2020. The results of this study are limited to the honesty of the respondents on the instrument prepared in this study

\section{Literature review}

The skill of phonological awareness is the conscious treatment of the phonemic level in speech, or it is the mental ability to manipulate the change in the phonemic level of words. In other words, phonological awareness means having the ability to know where linguistic sounds are produced and the output of these sounds and the way in which these sounds are formed together to form words, sentences, and utterances, with the ability to perceive the similarities and differences between these sounds, whether these sounds are single or in words and various linguistic expressions (Carvalhai et al., 2020). Phonological awareness is also defined as the set of practical activities of audio 
processing capabilities include phonological awareness, phonological memory, and rate of access for phonological information (Powell, \& Atkinson, 2021).

The most important of these abilities are the abilities of phonemic awareness, or what is sometimes known as the phonemic sensitivity of the audible language. These abilities can predict performance in reading tasks more than many other cognitive factors, which studies confirmed that these abilities are related to reading such as intelligence, knowledge of words and listening comprehension, and cognitive abilities (Saiegh-Haddad et al., 2020). This leads to the need to study the abilities of phonological awareness in children and its relationship to the process of word recognition, in addition to understanding the nature of phonological awareness and its different levels.

Phonological awareness helps in understanding the nature of the relationship between language and reading. Since in the past two decades, there has been remarkable progress in understanding this relationship, and perhaps the richest areas of research in this field are those related to the relationship between reading and language-related skills in the field. This relationship stems from the requirements of the writing system in which we want children to read. In the English alphabet system, the basic tasks facing the novice reader are to form the association between written symbols and speech sounds, combine phonetic symbols into syllables, combine syllables into words, and pronounce the phonemic string. The formation of this link requires the reader to realize that the word is divided into smaller units that actually represent an image of alphabetic writing (Lund, 2020).

From a second angle, the relationship between reading and language-related skills in the phonemic field becomes clear in several fields, such as sound processors at the word level and its components of syllables and smaller units. At the same time, it processes information in short-term memory and helps in the comprehension of sentences (Khasawneh, 2021).

It is recognized that learning to read in languages that follow the alphabetic system in writing requires maturity in the students' phonological awareness abilities, due to the fact that the written symbols represent the phonemic units of speech. These phonemic units are a group of abstract units, and therefore children must deal with phonemic units through their awareness of them, and their ability to discover their relationships with written symbols. Once children discover the association of certain sounds with the letters they represent, they are able to identify unfamiliar words (Kasawneh, 2021).

Some believe that phonological awareness is one of the components of the metalinguistic ability, which means the ability to use control processing, to perform emotional mental operations on the outputs of the mechanisms of understanding sentences, such as the mechanism of speech perception, the mechanism of lexical growth, and the mechanism of applying inferential rules (Khasawneh, 2021). 


\section{Previous studies}

Several previous research has been conducted on the use of phonological awareness and the problems teachers face when implementing its related strategies. For example, Benway et al (2021) identified the relationship between phonological awareness, vocabulary, and speech perception among preschoolers with speech disorders. The participants in this study were 110 children. The study developed a model based on vocabulary as a mediating factor. The results showed that model proved the relationship between speech perception and phonological awareness. The findings revealed that vocabulary play a vital role in helping students develop and improve their levels in language.

Chung and Bidelman (2021) examined the level of prosodic and phonological awareness among children in preschool. The results showed that children improve their pitch discrimination and prosodic awareness from preschool to fourth grade. The findings also showed that phonological awareness is very important in helping students acquire more vocabulary in the preschool stage until the fourth grade.

Goriot et al (2021) explored the role of bilingualism in increasing the phonological awareness among 294 students from the first three grades in a Dutch school. The study concluded that there is a small significant effect of bilingualism on the level of phonological awareness among the participants. The study found that memory skills are very important in the level of phonological awareness.

Henbest and Apel (2021) explored the role of spelling error analysis in predicting the linguistic knowledge of students and its relationship to phonological awareness. The Spelling Sensitivity System was used as an instrument to collect data. The findings revealed the presence of moderate negative correlation between spellings and performance on the phonological awareness task. The study also revealed that weak relationship between spelling errors and the orthographic pattern and phonological awareness measures.

Justi et al (2021) investigated the importance of phonological awareness among Brazilian Portuguese-speaking children. The study included 212 children. The study relied on the experimental design. The findings showed that the oblique model was the most appropriate to increase children's phonological awareness. The model was helpful in predicting the phoneme awareness among the first graders. The findings proved that phonological awareness can be measured by using specialized testing methods. 


\section{Methods}

The methodology used in this study was the descriptive and quantitative approach. This approach helps in collecting data from a specific population and presents results for discussion (Saunders et al., 2016).

\section{Sampling}

The population of the study consisted of all 217 male and female teachers of LDs in English language, who work in Irbid city, Jordan. The sample of the study was selected from this population, and their number was 140 teachers.

\section{Research Instrument}

The study developed a questionnaire as an instrument to collect data. The Likert-five point scale was used to measure the responses of teachers the statements of the questionnaire. The questionnaire consisted of two parts, the first to collect demographic information on the sample of the study. The second part consisted of 32 items and it measured the nature of problems of teaching phonological awareness to students with learning disabilities.

\section{Validity}

To verify the validity of the instrument, the researcher relied on the validity of the content, as he presented the tool to (10) specialized judges to ensure the appropriateness of each statement to what it measures and the extent to which the paragraphs of the scale are related to the variable to be measured. The judges also ensured the accuracy of statements, their formulation, degree of clarity, and their relevance to the fields. The researcher took the observations of the judges, omitted some phrases, and added others according to their instructions. The approval of the majority of judges on the statements was considered an indication of their validity, and thus the number of statements was

\section{Reliability}

After verifying the validity of the study instrument, its stability was confirmed using the test-re-test method after the same questionnaire was distributed to a sample of 35 
teachers from outside the study sample. The internal consistency was measured using the Cronbach alpha test. Table 1 shows that the reliability coefficient of the instrument as a whole was (0.819), which is acceptable for this study.

Table 1. Cronbach Alpha Test

\begin{tabular}{|c|c|}
\hline $\begin{array}{c}\text { Phonological Awareness problem Dimensions for learning } \\
\text { disabilities }\end{array}$ & Value of Cronbach Alpha \\
\hline English language curriculums & 0.717 \\
\hline learning disabilities Problems themselves & 0.863 \\
\hline learning disabilities educational environment & 0.723 \\
\hline English language teacher Problems & 0.685 \\
\hline Overall & $\mathbf{0 . 8 1 9}$ \\
\hline
\end{tabular}

Table 1 presents the value of the internal consistency coefficient for the instrument if the study. The value ranged from 0.685 to 0.863 . This value proves that the Cronbach Alpha coefficient values were higher than 0.60 , which means that the instrument was suitable for the objectives of this study.

\section{Data Analysis}

The statistical tools such as Samples T-Test, independent testy and One-Way ANOVA, and mean scores were used to analyse the obtained data. Means were used to explain the findings, as seen in the Table (2).

Table 2. The mean scores of the participant's responses to the instrument of the study

\begin{tabular}{|c|c|}
\hline Mean & Information \\
\hline $1,00-2.34$ & Disagree \\
\hline $2.34-3.68$ & Moderate Agree \\
\hline $3.68-5.01$ & Agree \\
\hline
\end{tabular}

Source: (Bryman \& Bell, 2011) 


\section{Findings and Discussion}

The study measured the responses of teachers based on gender and years of experience. The distribution of the sample was $33.9 \%$ male and $66.1 \%$ females. The sample also included $63.4 \%$ who have 5-10 years of experience while teachers with less than 5 years of experience constituted $18.8 \%$, and those with more than 10 years of experience constituted $17.7 \%$.

Table 3. The demographic description of the sample

\begin{tabular}{|l|l|c|l|}
\hline Variables & Category & N & \% \\
\hline Gender & Male & 40 & 28.57 \\
& Female & 100 & 71.4 \\
\hline \multirow{2}{*}{ Years of experience } & less than 5 years & 25 & 17.85 \\
& 5-10 years & 98 & 70 \\
& more than 10 years & 23 & 16.42 \\
\hline
\end{tabular}

To determine the Teaching Phonological Awareness problems to learn disabilities students from the teachers' perspective in Irbid city, Jordan, for each of the questionnaire elements, the researcher used standard deviation and. Means.

Table 4. the mean scores and standard deviation of the statements of the questionnaire

\begin{tabular}{|c|l|c|c|c|}
\hline $\mathbf{N}$ & Item & Mean & St. deviation & Result \\
\hline & $\begin{array}{l}\text { English language curriculums for learning } \\
\text { disabilities }\end{array}$ & 1.04 & $\mathrm{~A}$ \\
\hline 1 & $\begin{array}{l}\text { The English language curriculum objectives do not } \\
\text { take into account the abilities of learning disabilities }\end{array}$ & 3.94 & 1.07 & $\mathrm{~A}$ \\
\hline 2 & $\begin{array}{l}\text { The English language curriculum subjects are not } \\
\text { suitable to the linguistic development of learning } \\
\text { disabilities }\end{array}$ & 3.97 & 1.24 & $\mathrm{MA}$ \\
\hline 3 & $\begin{array}{l}\text { The textbook lacks figures, pictures, or illustrations } \\
\text { for learning disabilities }\end{array}$ & 3.67 & 1.27 & $\mathrm{MA}$ \\
\hline 4 & $\begin{array}{l}\text { The English language curriculum subjects are not } \\
\text { related to the culture of learning disabilities }\end{array}$ & 3.58 & 1.08 & $\mathrm{~A}$ \\
\hline 5 & $\begin{array}{l}\text { Classroom activities are limited in the curriculum of } \\
\text { English language }\end{array}$ & 3.87 & $\mathbf{0 . 7 7}$ & $\mathrm{A}$ \\
\hline & Total & $\mathbf{3 . 8 0}$ & $\mathbf{2}$ \\
\hline
\end{tabular}




\begin{tabular}{|c|c|c|c|c|}
\hline & $\begin{array}{l}\text { Problems related to the learning disabilities } \\
\text { themselves }\end{array}$ & & & \\
\hline 6 & $\begin{array}{l}\text { Students with LDs do not accept learning English } \\
\text { language }\end{array}$ & 3.48 & 1.41 & MA \\
\hline 7 & $\begin{array}{l}\text { Weakness of the mother tongue affects learning } \\
\text { Phonological Awareness of learning disabilities. }\end{array}$ & 3.94 & 1.03 & A \\
\hline 8 & $\begin{array}{l}\text { The low level of language proficiency among LDs } \\
\text { students limits their chances of learning English } \\
\text { language }\end{array}$ & 3.97 & 1.02 & A \\
\hline 9 & $\begin{array}{l}\text { Learning disabilities lack the basics American Sign } \\
\text { Language }\end{array}$ & 3.72 & 1.25 & A \\
\hline 10 & $\begin{array}{l}\text { English Learning disabilities do not use the in their } \\
\text { daily lives }\end{array}$ & 3.45 & 1.15 & MA \\
\hline 11 & $\begin{array}{l}\text { Learning English disabilities do not start at an early } \\
\text { stages }\end{array}$ & 3.38 & 1.31 & MA \\
\hline 12 & $\begin{array}{l}\text { for fear of making mistakes while using the English } \\
\text { language Learning English disabilities avoid } \\
\text { participating in the classroom }\end{array}$ & 3.42 & 1.25 & MA \\
\hline \multirow[t]{3}{*}{13} & $\begin{array}{l}\text { Learning disabilities turn to those who do their } \\
\text { homework in English on their behalf }\end{array}$ & 4.00 & 0.98 & A \\
\hline & Total & 3.67 & 0.85 & MA \\
\hline & $\begin{array}{l}\text { Learning English disabilities educational } \\
\text { environment }\end{array}$ & & & \\
\hline 14 & $\begin{array}{l}\text { The educational of Learning English disabilities } \\
\text { environment lacks modern teaching aids }\end{array}$ & 3.89 & 1.09 & A \\
\hline 15 & $\begin{array}{l}\text { resource rooms not investing in teaching-learning } \\
\text { English disabilities. }\end{array}$ & 3.87 & 1.11 & A \\
\hline 16 & $\begin{array}{l}\text { The textbooks do not include activities related } \\
\text { to Teaching Phonological Awareness to learn } \\
\text { disabilities students }\end{array}$ & 3.63 & 1.21 & MA \\
\hline 17 & $\begin{array}{l}\text { Educational environment needs financial allocations } \\
\text { for learning English disabilities by the school } \\
\text { administration }\end{array}$ & 3.73 & 1.21 & A \\
\hline \multirow[t]{3}{*}{18} & $\begin{array}{l}\text { learning of English affects by Placing it at the end of } \\
\text { the school da }\end{array}$ & 3.89 & 1.07 & A \\
\hline & Total & 3.80 & 0.79 & A \\
\hline & Problems related to the English language teacher & & & \\
\hline 19 & $\begin{array}{l}\text { Teacher that learning English language disabilities } \\
\text { are unable to learn the English language }\end{array}$ & 3.20 & 1.27 & MA \\
\hline 20 & $\begin{array}{l}\text { English teachers are not qualified enough to teach } \\
\text { students with learning disabilities }\end{array}$ & 3.22 & 1.29 & MA \\
\hline
\end{tabular}




\begin{tabular}{|c|c|c|c|c|}
\hline 21 & Teachers' weakness to teach learning disabilities & 3.25 & 1.26 & MA \\
\hline 22 & $\begin{array}{l}\text { Teachers' weakness in the knowledge in the } \\
\text { Phonological Awareness }\end{array}$ & 3.16 & 1.32 & MA \\
\hline 23 & $\begin{array}{l}\text { The English language is widely used in Teaching } \\
\text { Phonological Awareness }\end{array}$ & 3.23 & 1.32 & MA \\
\hline 24 & $\begin{array}{l}\text { Teachers do not use the appropriate strategies of } \\
\text { Teaching Phonological Awareness. }\end{array}$ & 3.30 & 1.37 & MA \\
\hline 25 & $\begin{array}{l}\text { The teacher of English language disabilities finds } \\
\text { it difficult to assess the achievement level of the } \\
\text { learning disabilities }\end{array}$ & 2.34 & 1.27 & MA \\
\hline 26 & $\begin{array}{l}\text { The teacher of English language disabilities does } \\
\text { not use clear strategies to facilitate the Phonological } \\
\text { Awareness disabilities }\end{array}$ & 3.15 & 1.44 & MA \\
\hline 27 & $\begin{array}{l}\text { Teachers do not receive enough support because } \\
\text { they deal with learning disabilities students with } \\
\text { special needs }\end{array}$ & 3.39 & 1.25 & MA \\
\hline 28 & $\begin{array}{l}\text { Lack of training courses for English language } \\
\text { disabilities teacher on teaching methods for learning } \\
\text { disabilities }\end{array}$ & 3.20 & 1.37 & MA \\
\hline 29 & $\begin{array}{l}\text { The lack of supervisors specialized in special } \\
\text { education to provide help to teachers. }\end{array}$ & 3.08 & 1.39 & MA \\
\hline & Total & 3.17 & 0.58 & MA \\
\hline & Overall & 3.62 & 0.52 & MA \\
\hline
\end{tabular}

Table 4 revealed that the overall mean score for the problems of teaching phonological awareness was (3.62) with a standard deviation of (0.52). This indicates that the level of problems is moderately significant. Statement No. 2 had the highest means score with (3.97), while item 4 , had the lowest mean score (3.59). Table 4 also revealed that the mean score of the problems related to curriculum was (3.80) with a standard deviation of (0.77).

These results show that problems related to curriculum, in general, constitute challenges phonological awareness including the lack of suitable curriculum objectives for the abilities of learning disabilities.

Item 13 had the highest means score among the items of problems related to the learning disabilities themselves (4.00). Item 11 had the lowest mean score (3.38). The mean score of problems related to the learning disabilities themselves was (3.67) with a standard deviation of (0.84).

It is noticed from these results that the problems related to students with learning disabilities show that such students rely on others for help to perform their homework related to the English language disabilities. 
The results related to problems related to teachers show that these teachers fail to apply different strategies to help students with learning disabilities. The lack of knowledge of the teacher makes it difficult for students to acquire the necessary skills to increase the levels of phonological awareness.

To identify the statistically significant differences between males and female teachers and the difference according to years of experience, the independent sample $t$ test and One Way Anova were used.

Table 5. The $\mathrm{t}$ test for the response of the participants based on gender

\begin{tabular}{|c|c|c|c|c|c|c|}
\hline Variables & $\mathbf{N}$ & Mean & St. deviation & df & t & Sig \\
\hline Male & 63 & 3.55 & 0.60 & 184 & 0.911 & 0.135 \\
\hline Female & 123 & 3.63 & 0.50 & & & \\
\hline
\end{tabular}

Table (5) showed male teachers' mean score was (3.55) and females' score was (3.63). The table shows no significant impact of gender toward the problems of teaching phonological awareness.

Table 6. The ANOVA test of the responses of the participants based on years of experience

\begin{tabular}{|c|c|c|c|c|c|c|}
\hline Variable & Groups & Sum of Squares & df & Mean Square & F & Sig \\
\hline $\begin{array}{c}\text { Years of } \\
\text { experience }\end{array}$ & $\begin{array}{c}\text { Between } \\
\text { groups }\end{array}$ & 0.498 & 2 & 0.249 & 0.871 & 0.410 \\
\cline { 2 - 7 } & $\begin{array}{c}\text { Within } \\
\text { groups }\end{array}$ & 52.38 & 183 & 0.286 & & \\
\cline { 2 - 7 } & Total & 52.88 & 185 & & & \\
\hline
\end{tabular}

Table (6) reveals the absence of differences between the responses of the participants based on the years of experience. The level of significance (0.410) shows that there was no statistical evidence of the effect of years of experience on the attitudes toward the problems of teaching phonological awareness to students with LDs.

These results showed that the problems of teaching phonological awareness to students with LDs are multidimensional. Some of these problems are related to the teachers, to the school environment, and to the students themselves. The school curricula lack sufficient support for both the teacher and the student in understanding the concepts of phonological awareness. The findings from this study show the need for deeper investigation into the importance of phonological awareness to improve the English levels of students with LDs. 


\section{Conclusion}

This study presented an exploration to the problems related to teaching phonological awareness to students with LDs in English language from the perspectives of teachers. The study also investigates the impact of gender and the years of experience of the teacher on their attitudes and opinions on these problems. The findings revealed that these problems are either related to the textbooks, to the students themselves or to teachers. The findings also indicated that the level of these problems was moderate and gender and experience had no impact on the attitudes toward these problems. The study recommended that more training should be provided to teachers on the optimal methods of teaching phonological awareness to students with learning disabilities.

\section{Acknowledgments}

The authors extend their appreciation to the Deanship of Scientific Research at King Khalid University for funding this work through Big Research Groups under grant number (RGP.2 /103/42). 


\section{References}

Benway, N. R., Garcia, K., Hitchcock, E., McAllister, T., Leece, M. C., Wang, Q., \& Preston, J. L. (2021). Associations between speech perception, vocabulary, and phonological awareness skill in school-aged children with speech sound disorders. Journal of Speech, Language, and Hearing Research, 64(2), 452-463.

Carvalhais, L., Limpo, T., Richardson, U., \& Castro, S. L. (2020). Effects of the Portuguese Graphogame on reading, spelling, and phonological awareness in second graders struggling to read. The Journal of Writing Research, 12(1).

Chung, W. L., \& Bidelman, G. M. (2021). Mandarin-speaking preschoolers' pitch discrimination, prosodic and phonological awareness, and their relation to receptive vocabulary and reading abilities. Reading and Writing, 34(2), 337-353.

Goriot, C., Unsworth, S., van Hout, R., Broersma, M., \& McQueen, J. M. (2021). Differences in phonological awareness performance: Are there positive or negative effects of bilingual experience? Linguistic Approaches to Bilingualism, 11(3), 418451.

Henbest, V. S., \& Apel, K. (2021). The Relation Between a Systematic Analysis of Spelling and Orthographic and Phonological Awareness Skills in First-Grade Children. Language, Speech, and Hearing Services in Schools, 1-13.

Justi, C. N. G., Henriques, F. G., \& Justi, F. R. D. R. (2021). The dimensionality of phonological awareness among Brazilian Portuguese-speaking children: a longitudinal study. Psicologia: Reflexão e Crítica, 34.

Khasawneh, M. A. (2021). The effect of the spread of the new COVID-19 on the psychological and social adaptation of families of persons with disabilities in the Kingdom of Saudi Arabia. Health Psychology Report, 9(3), 264-275. DOI: https:// doi.org/10.5114/hpr.2020.99003

Khasawneh, M. A. S. (2021). Language skills and their relationship to learning difficulties in English language from the students' point of view. Science and Education, 2(9), 261-272. DOI: 10.34293/education.v9i4.4082

Khasawneh, M. A. S. (2021). Methods of resource room management for teachers of learning disabilities in English language in light of some variables. Science and Education, 2(9), 240-249. DOI: 10.30659/e.6.2.213-221

Kwakkel, H., Droop, M., Verhoeven, L., \& Segers, E. (2021). The impact of lexical skills and executive functioning on L1 and L2 phonological awareness in bilingual kindergarten. Learning and Individual Differences, 88, 102009. 
Landerl, K., Freudenthaler, H. H., Heene, M., De Jong, P. F., Desrochers, A., Manolitsis, G., ... \& Georgiou, G. K. (2019). Phonological awareness and rapid automatized naming as longitudinal predictors of reading in five alphabetic orthographies with varying degrees of consistency. Scientific Studies of Reading, 23(3), 220-234.

Lederberg, A. R., Branum-Martin, L., Webb, M. Y., Schick, B., Antia, S., Easterbrooks, S. R., \& Connor, C. M. (2019). Modality and interrelations among language, reading, spoken phonological awareness, and fingerspelling. The Journal of Deaf Studies and Deaf Education, 24(4), 408-423

Lund, E. (2020). The relation between vocabulary knowledge and phonological awareness in children with cochlear implants. Journal of Speech, Language, and Hearing Research, 63(7), 2386-2402.

Powell, D., \& Atkinson, L. (2021). Unraveling the links between rapid automatized naming (RAN), phonological awareness, and reading. Journal of Educational Psychology, 113(4), 706.

Saiegh-Haddad, E., Shahbari-Kassem, A., \& Schiff, R. (2020). Phonological awareness in Arabic: the role of phonological distance, phonological-unit size, and SES. Reading and writing, 1-26.

Zarić, J., Hasselhorn, M., \& Nagler, T. (2021). Orthographic knowledge predicts reading and spelling skills over and above general intelligence and phonological awareness. European Journal of Psychology of Education, 36(1), 21-43.凶

\section{Author}

\section{* Mohamad Ahmad Saleem Khasawneh}

ORCID: https://orcid.org/0000-0002-1390-3765

How to reference this article: Khasawneh, M. A. S. (2021) Problems of Teaching Phonological Awareness to Learning Disabilities Students. GIST - Education and Learning Research Journal, 23, 135-150. https://doi.org/10.26817/16925777.961 